\title{
Analysis of whole-cell proteins of Streptococcus thermophilus by 2 electrophoretic methods
}

\author{
C Guimont, D Clary, P Bracquart** \\ Laboratoire de Biochimie Appliquée, Associé à I'INRA, Université de Nancy I, \\ BP 239, 54506 Vandœuvre-lès-Nancy Cedex, France
}

(Received 23 March 1993; accepted 16 August 1993)

\begin{abstract}
Summary - The protein fingerprinting obtained by 2 electrophoretic procedures was used to compare strains of Streptococcus thermophilus. Whole-cell soluble proteins were extracted and separated by $10-28 \%$ polyacrylamide gradient gel electrophoresis and $\mathrm{pH} 2.9-9.2$ isoelectric focusing. Electrophoretic migration of proteins from $8 \mathrm{~S}$ thermophilus strains produced highly resolutive and reproducible patterns with 30-40 distinct bands on SDS-PAGE and 20-25 bands on isoelectric focusing. Proteins of $S$ thermophilus display similar or almost identical patterns and major strains could be clustered with a tight relation with the strain type ATCC19258. Only strain IP 6631 showed a pattern with fewer bands in SDS-PAGE and was clustered alone. Two strains (PB 18 and CNRZ 308 ) appeared to be distinguished by the relative importance of a typical band. Significant variations were detected by analysis of protein banding patterns for the same strains cultured in different physiological conditions.
\end{abstract}

\section{Streptococcus thermophilus / whole-cell proteins / SDS-PAGE / isoelectric focusing}

Résumé - Analyse des protéines de cellules entières de Streptococcus thermophilus par 2 méthodes électrophorétiques. Le profil protéique obtenu par 2 méthodes électrophorétiques est utilisé pour comparer différentes souches de Streptococcus thermophilus. Les protéines solubles des cellules entières sont extraites puis séparées par électrophorèse en gradient de gel de polyacrylamide (10-28\%) et par électrophorèse en gradient de $\mathrm{pH} 2,9-9,2$. Les profils protéiques obtenus à partir de 8 souches d'origines diverses sont bien résolus et reproductibles : ils permettent de distinguer 30 à 40 bandes en PAGE-SDS et 20 à 25 bandes en isoélectrofocalisation. Dans les 2 cas, les électrophorégrammes des souches sont presque identiques et les souches peuvent être corrélées à la souche de référence ATCC 19258. Parmi ces souches, la souche IP 6631 a un profil différent en PAGE-SDS et ne peut être associée aux autres. Deux souches (CNRZ 308 et PB 18) se distinguent par l'importance relative d'une bande. Des différences significatives peuvent être détectées par

\footnotetext{
- Present address: SANOFI Bio-Industrie, 16, rue de la Gare, BP 20, 77260 La Ferté Sous Jouarre, France.

* Correspondence and reprints
} 
l'analyse des profils protéiques de ces 2 souches cultivées dans des conditions physiologiques différentes.

Streptococcus thermophilus / protéine / PAGE-SDS / électrophorèse isoélectrique

\section{INTRODUCTION}

Numerous strains of lactic acid bacteria are used in the production of various cultured dairy products. Among the dairy starters purchased, strains of Streptococcus thermophilus are used in fermented milks such as yoghurt, and in cheeses where a high temperature of manufacture is needed (emmental, gruyère).

The properties of final food product depend on the capacities of each strain that makes up the starter. Therefore, a practical means to identify and characterize individual strains from a pure or mixed starter culture must be available. Among the various methods currently used for identification and characterization of microorganisms, the electrophoresis of cellular proteins has proved to be a reliable and rapid procedure (Kersters and De Ley, 1975; Jackman, 1985; Schleifer and Kilpper-Bälz, 1987). Electrophoretic protein pattern analysis has been applied for characterizing lactic streptococci (Jarvis and Wolff, 1979; Elliott et al, 1991), S thermophilus (Hemme and Nardi, 1980; Zourari et al, 1992) and lactobacilli (Baer, 1987; Dicks and van Vuuren, 1987). Kersters and Pot (1991) are presently constructing a data bank of SDS-PAGE fingerprinting for confirmation of the authenticity of lactic acid bacteria strains and evaluation of existing classification schemes.

Consequently, in this study we have attempted to investigate the application of the combined use of 2 different electrophoretic methods for differentiating strains of $S$ thermophilus. This study also deals with the location and identification of proteins recovered specifically in different physiological conditions.

\section{MATERIALS AND METHODS}

\section{Bacterial strains and culture conditions}

The strains used in this study were obtained from the INRA collection (CNRZ 302, CNRZ 308, CNRZ 368, CNRZ 385, CNRZ 455), the Institut Pasteur (IP 6631), the American Type Culture Collection (ATCC 19258) and from our own laboratory (PB 18). Stock cultures stored at $-20^{\circ} \mathrm{C}$ were prepared in $10 \%$ reconstituted milk inoculated at $2 \%$ and incubated for $3 \mathrm{~h}$ at $42^{\circ} \mathrm{C}$.

An overnight preculture was prepared from stock culture and used to inoculate $200 \mathrm{ml}(2 \%$ $\mathrm{v} / \mathrm{v}$ inoculum) of TPPY broth (Bracquart, 1981), M17 (Terzaghi and Sandine, 1975) or ELT medium (specific laboratory medium). This medium contains: yeast extract, $8 \mathrm{~g}$; lactose, $10 \mathrm{~g}$; sodium hydrogen carbonate, $2 \mathrm{~g}$; distilled water, $1000 \mathrm{ml}$. The M17 medium was obtained from Merck (Darmstadt, Germany).

These cultures were incubated at $42^{\circ} \mathrm{C}$ and the bacterial growth was monitored at $580 \mathrm{~nm}$.

\section{Preparation of fractions of soluble proteins}

Cells from the end of exponential phase were. harvested by centrifugation ( $8500 \mathrm{~g}$ for $10 \mathrm{~min}$ ). After washing twice in $50 \mathrm{mmol} / \mathrm{l}$ sodium phosphate buffer, $\mathrm{pH} 7.0$, the cell pellet was frozen at $-20^{\circ} \mathrm{C}$ overnight. After thawing, the pellet $(500$ $\mathrm{mg}$ ) was suspended in the same buffer and sonicated for $3 \mathrm{~min}$ (50\% pulse, power 3 , Vibracell 600 W, Bioblock Scientific, France). The soluble protein fraction of the supernatant was obtained 
after centrifugation (19 $500 \mathrm{~g}$ for $10 \mathrm{~min}$ ) and the protein content was measured by colorimetric method (Bradford, 1976) using bovine serum albumin (Sigma, St Louis, MO, USA) for the standard curve.

A specific volume corresponding to $1 \mathrm{mg}$ of proteins was submitted to lyophilization. The lyophilized samples were dissolved in $25 \mathrm{mmol} / \mathrm{l}$ Tris- $\mathrm{HCl}, 2 \% \mathrm{SDS}, 47 \mathrm{mmol} / \mathrm{l}$ 2-mercaptoethanol, $\mathrm{pH} 6.8$ buffer. After boiling for $5 \mathrm{~min}$, the protein samples were mixed with a $50 \%$ glycerol solution containing bromophenol blue $(0.01 \%) .100 \mu \mathrm{g}$ and $750 \mu \mathrm{g}$ of proteins were applied to gels for SDS-PAGE electrophoresis and isoelectric focusing, respectively.

\section{$10-28 \%$ polyacrylamide discontinuous gel electrophoresis}

The electrophoretic analyses were performed according to Laemmli and Favre (1973) with a vertical system 2001 for SDS-PAGE (LKB, Bromma, Sweden). Acrylamide, N,N'-methylene bisacrylamide and SDS were purchased from BDH Chemicals (Poole, UK), ammonium persulfate, 2-mercaptoethanol, bromophenol blue and Coomassie blue R-250 from Merck.

The discontinuous polyacrylamide gel was composed of a stacking gel ( $\mathrm{T}=5.43 \% ; \mathrm{C}=$ $2.7 \%$ in $121 \mathrm{mmol} / \mathrm{l}$ Tris- $\mathrm{HCl}, \mathrm{pH} 6.8$ buffer) and a $10-28 \%$ acrylamide gradient separating gel in $379 \mathrm{mmol} / \mathrm{l}$ Tris- $\mathrm{HCl}, \mathrm{pH} 8.8$ buffer. Acrylamide gradient was achieved with solutions I $(T=$ $10.3 \% ; C=2.7 \%)$ and II ( $T=28.7 \% ; C=2.7 \%$; sucrose $=3.9 \%$ ) in a gradient former (Hoefer, San Francisco, CA, USA). Electrophoresis was performed at $60 \mathrm{~mA}$ until the tracking dye migrated to the bottom of the gel.

Proteins were fixed by soaking the gels immediately in $12 \%$ TCA for $30 \mathrm{~min}$. Subsequent$\mathrm{ly}$, the gels were colored in a solution of $0.1 \%$ Coomassie blue R-250 in 2\% TCA in methanol/ $\mathrm{H}_{2} \mathrm{O}(1 / 1: \mathrm{v} / \mathrm{v})$. Destaining was achieved by washing the gels in methanol/ $\mathrm{H}_{2} \mathrm{O} /$ acetic acid $(3 / 6.25 / 0.75: \mathrm{v} / \mathrm{v} / \mathrm{v})$. Molecular masses were estimated using the linear relationship between the $\log$ of the molecular weight of the standards (Sigma Chemical Co, St Louis, MO, USA) and relative mobility $(r=0.99)$.

The protein patterns were highly reproducible both within and between gels. Duplicate protein samples from 2 strains electrophoresed on 2 dif- ferent gels were compared, and their average similarity based on the whole patterns were in good agreement with a mean and SD of $96.8 \pm$ $0.4 \%$.

\section{Isoelectric focusing}

The specific parameters for isoelectric focusing were modified in the laboratory (Sanogo et al, 1990). A 5\% polyacrylamide gel was used with a $\mathrm{pH}$ gradient from 2.9 to 9.2 . Average similarity between the gels was $93.6 \pm 0.5 \%$.

\section{Scanning of gels}

The stained protein patterns were scanned with an Ultroscan XL densitometer (LKB, Bromma, Sweden) connected to an IBM computer (AT model). The gel scan module was adjusted to the following settings: absorption wavelength $650 \mathrm{~nm}$; slit width, $800 \mu \mathrm{m}$; area reject $1 \%$; no background was subtracted. The raw data were aligned by computer on the initial interface of the gel. The similarity between any pairs of densitometric tracings of protein patterns was calculated using the Pearson product - moment correlation coefficient $(\eta)$.

\section{RESULTS}

\section{SDS-PAGE protein patterns}

The electrophoretic patterns of $S$ thermophilus were analyzed on 8 strains obtained from various collections. They originated from different dairy products and countries, and were known to have different physiological and biochemical characteristics.

The protein fingerprints of the studied strains showed 3 major groups of sharp and differently clustered bands (fig 1). When compared visually, the whole-cell protein banding patterns seem to be relatively similar. After scanning and tight cor- 


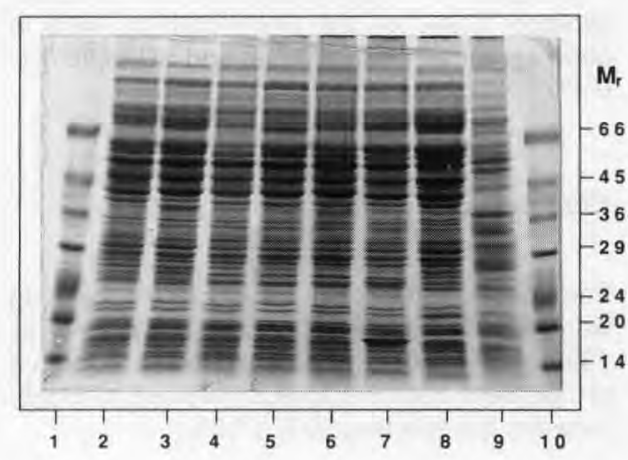

Fig 1. SDS-PAGE patterns of the whole-cell proteins of $S$ thermophilus strains. Lane 2, CNRZ 302; 3, CNRZ 308; 4, CNRZ 385; 5 , CNRZ 368; 6, CNRZ 455; 7, PB18; 8, ATCC 19258; 9, IP 6631. Lanes 1 and 10, SDS-PAGE molecular mass standards.

Profils PAGE-SDS des protéines de cellules entières des souches de $\mathrm{S}$ thermophilus.

relation between them, the strains could be clustered in the following order: CNRZ 455 and CNRZ 308; CNRZ 368, CNRZ 385, CNRZ 302 and PB 18; and then IP 6631. This last strain showed a strikingly exceptional protein pattern with a large number of bands missing in the profile, in particular in the range of large molecular masses. A specific 90-100 kDa protein, present in all other strains, had disappeared. Overall this strain contained some additional and intense bands. Among them, 2 proteins with molecular mass of 50 and $38 \mathrm{kDa}$, accounting for $8.2 \pm 1.5 \%$ and $7.5 \pm 1.0 \%$ of the relative area, were observed (fig 1; lane 9 ).

The strains CNRZ 308 and PB18 showed a distinct fingerprint with a protein band of high intensity (fig 1, lanes 3 and 7). This was a protein of $38 \mathrm{kDa}$ for the strain CNRZ 308 and $18 \mathrm{kDa}$ for the strain PB 18. These proteins accounted for $7.1 \pm$ $0.8 \%$ and $12.0 \pm 1.5 \%$ of the relative area respectively, compared with $1.4 \pm 0.3 \%$ and $2.0 \pm 0.6 \%$ in the other strains.

\section{Isoelectric focusing patterns}

The $\mathrm{pH} 2.9-9.2$ gradient gel was shown to resolve numerous bands $(20-25)$ over the acidic region and a small group of bands accumulated over the more basic region (fig 2). There was a lack of bands in the $\mathrm{pH}$ range $7-8.5$, which could be explained by a poor fixation of basic proteins by trichloroacetic acid, as reported by Steck et al (1980). Protein patterns were shown to be almost identical without a specific pattern for the strain IP 6631. The patterns of CNRZ 308, CNRZ 368, ATCC 19258 and IP 6631 were grouped with a common band of pl 5.8 of high intensity in comparison to the 4 other strains (fig 2, lanes 2, 4 , 7 and 8 ). The protein profile of the strain

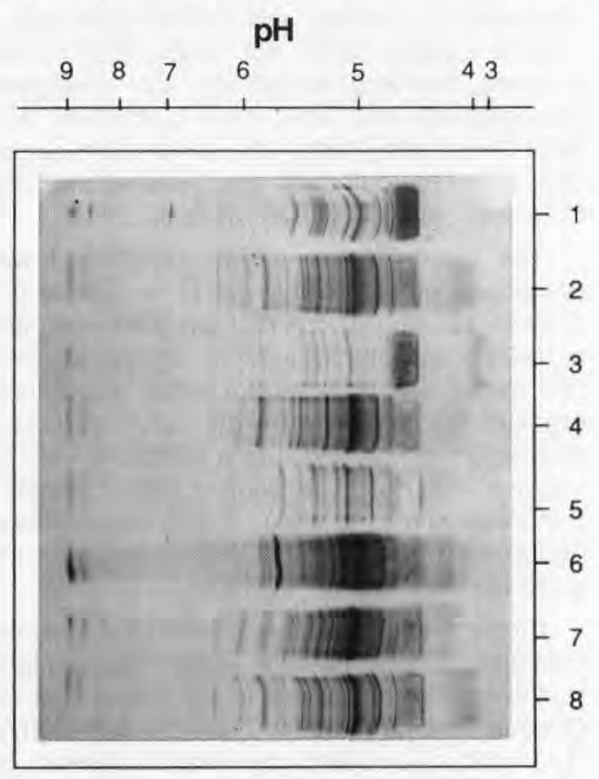

Fig 2. Isoelectric focusing electrophoresis patterns of the whole-cell proteins of $S$ thermophilus strains. Lane 1, CNRZ 302; 2, CNRZ 308; 3 , CNRZ 385; 4, CNRZ 368; 5, CNRZ 455; 6, PB18; 7, ATCC 19258; 8, IP 6631.

Profils d'électrophorèse isoélectrique des protéines de cellules entières des souches de $\mathrm{S}$ thermophilus. 
PB18 was again distinguished by a band of the highest intensity of coloration localized at pl 5.7 (fig 2, lane 6).

\section{Influence of growth medium on protein patterns}

In order to verify whether the electrophoretic procedures were useful for studying protein pattern variations within the strains of $S$ thermophilus, similar work was carried out with the 2 strains CNRZ 308 and PB18 in different physiological conditions. The whole-cell proteins were prepared from
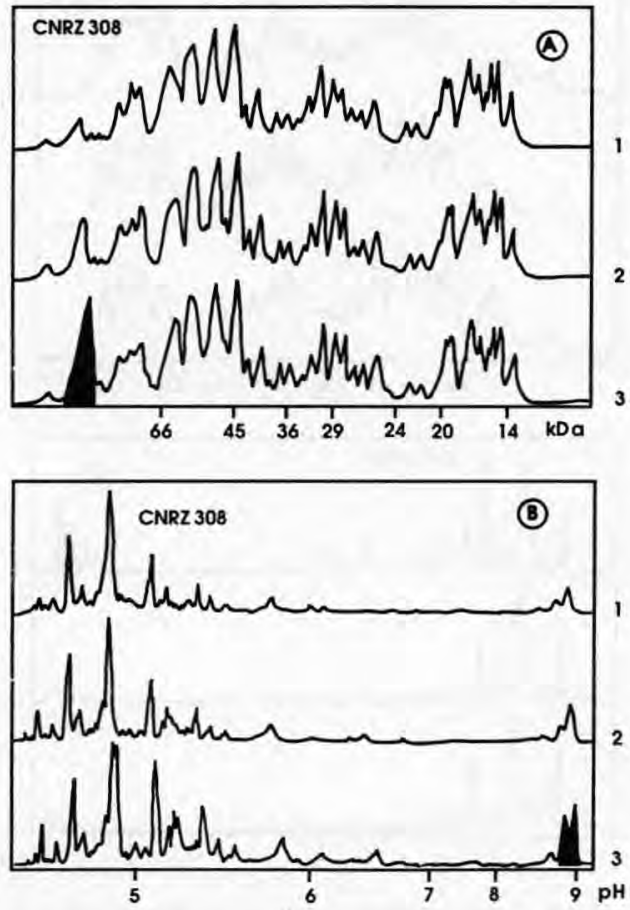

Fig 3. Densitometric traces of whole-cell protein patterns of $S$ thermophilus CNRZ 308 grown in different media. A, SDS-PAGE; B, isoelectric focusing. Lane 1, TPPY; 2, ELT; 3, M17.

Tracé densitométrique des profils protéiques de cellules entières de $\mathrm{S}$ thermophilus CNRZ 308 cultivées dans différents milieux. bacteria grown in buffered (M17 and ELT) and non-buffered (TPPY) media. Protein patterns were analyzed by densitometry and the scans are shown in figures 3 and 4. Significant results from the numerical analysis of scans are presented in figure $5 \mathrm{~A}$.

The SDS-PAGE patterns were not significantly different in comparison to the overall reproducibility values, except that one protein with molecular mass of 90-100 $\mathrm{kDa}$ lighted up strongly in the 2 strains growing in M17 compared with ELT and TPPY (fig 5A). In addition, the scan of isoelectric focusing patterns revealed significant differences with proteins of $\mathrm{pl} 8.8$ bet-
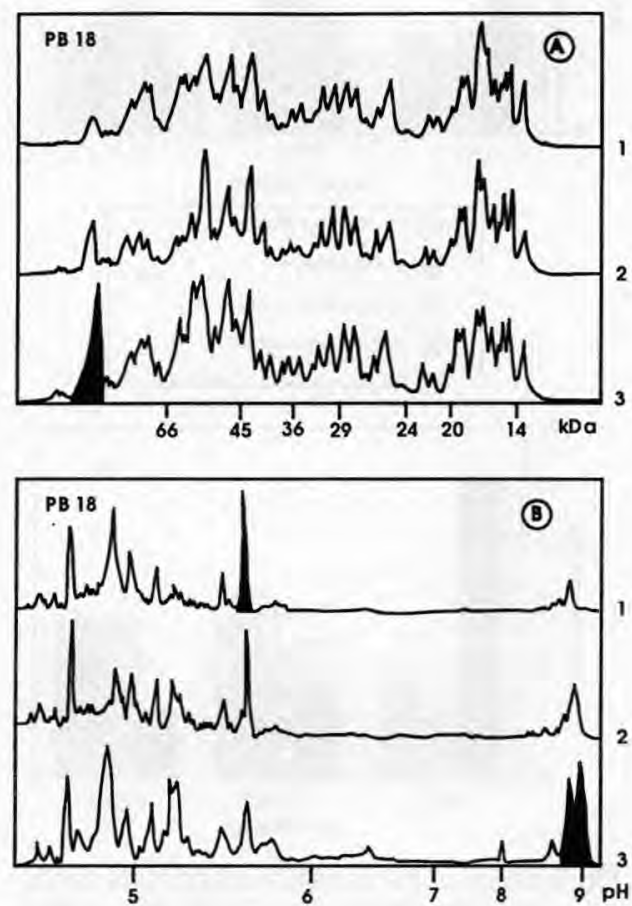

Fig 4. Densitometric traces of whole-cell protein patterns of $S$ thermophilus PB18 grown in different media. A, PAGE-SDS; B, isoelectric focusing. Lane 1, TPPY; 2, ELT; 3, M17.

Tracé densitométrique des profils protéiques de cellules entières de $\mathrm{S}$ thermophilus PB 18 cultivées dans différents milieux. 
ter expressed by the 2 strains growing in M17. Both patterns from strain PB18 showed that the 2 proteins of $18 \mathrm{kDa}$ and pl 5.7 were less expressed in M17 (fig 5A). Comparatively, the pattern from strain CNRZ 308 showed that the protein of 38 $\mathrm{kDa}$ was expressed in TPPY as well as in ELT or M17. It could be noted that the group of proteins better expressed in $\mathrm{M} 17$ or in TPPY $(90-100 \mathrm{kDa}$ and $\mathrm{pl} 8.8 ; 18$
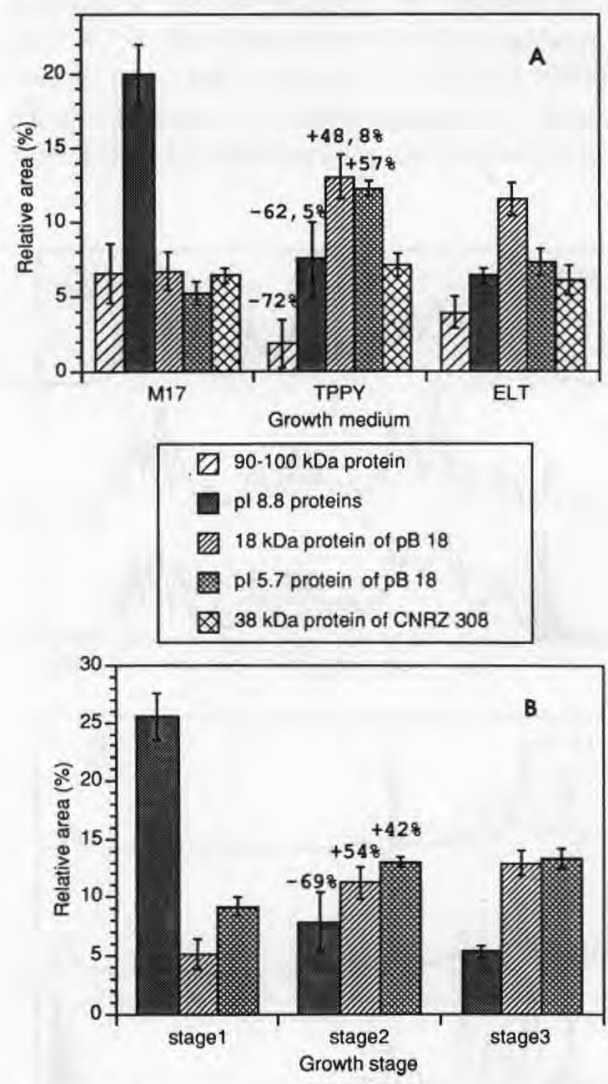

Fig 5. Study of the variations of proteins bands visualized with PB18 and CNRZ 308 strains grown under different conditions. A. Different growth media; B. Different growth stages. Stage 1: early exponential phase; stage 2: late exponential phase; stage 3 : stationary phase.

Étude des variations des bandes protéiques observées avec les souches PB 18 et CNRZ 308 cultivées dans diverses conditions.
$\mathrm{kDa}$ and $\mathrm{pl} 5.7$ ) accounted for similar percentage of variation ( -72 and $-62.5 \%$; +48.8 and $+57 \%$ ) in the 2 cases.

\section{Influence of growth stage on protein patterns}

Previous patterns seemed to show similar expression of groups of proteins in the different media. However, strain PB 18 grown in the TPPY medium was shown to present a different pattern. We have also chosen to look at proteins expressed along growth stages of the 2 strains (figs 6,7 ).
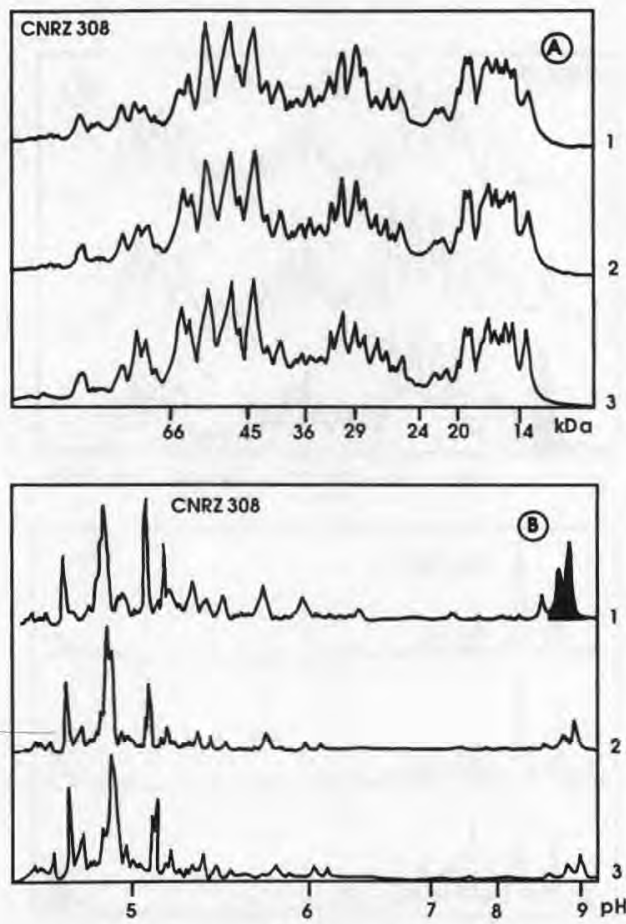

Fig 6. Densitometric traces of whole-cell protein patterns of S thermophilus CNRZ 308 grown during various times. A, SDS-PAGE; B, isoelectric focusing. Lane 1 , exponential phase; 2 , late exponential phase; 3 , stationary phase.

Tracé densitométrique des profils protéiques de cellules entières de S thermophilus CNRZ 308 cultivées pendant des temps différents. 

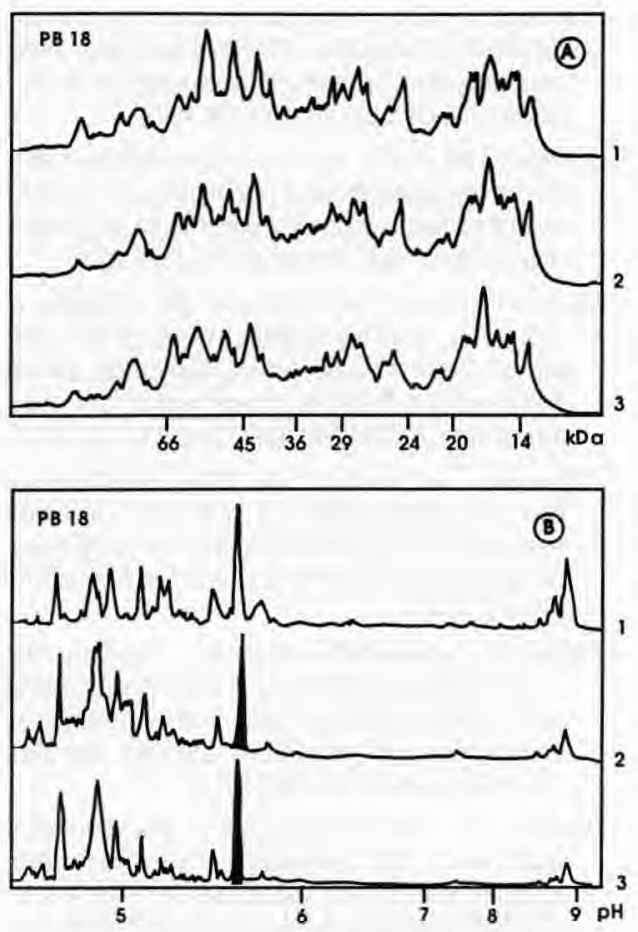

Fig 7. Densitometry tracing of whole-cell protein patterns of $S$ thermophilus PB 18 grown during various times. A, SDS-PAGE; B, isoelectric focusing. Lanes 1 , exponential phase; 2 , late exponential phase; 3 , stationary phase.

Tracé densitométrique des profils protéiques de cellules entières de $S$ thermophilus $P B 18$ cultivées pendant des temps différents.

The results of the numerical analysis are presented in figure $5 \mathrm{~B}$ as above. The SDS-PAGE as well as the isoelectric focusing patterns revealed a diminution of intensity of bands with the increasing age of strains cultured in TPPY. Only the group of basic proteins ( $\mathrm{pl}$ 8.8) showed a significant diminution $(-69 \%)$ of their expression in the late exponential phase (fig $5 \mathrm{~B}$, stage 2). Moreover, the strain PB18 presented the $18 \mathrm{kDa}$ protein and the $\mathrm{pl} 5.7$ protein was better expressed in the late exponen- tial phase than in the early phase $(+54 \%$; $+42 \%$ ).

\section{DISCUSSION}

Electrophoresis on (i) $10-28 \%$ gradient polyacrylamide gel and (ii) $\mathrm{pH} 2.9-9.2$ gradient gel, applied to $S$ thermophilus strains, showed high resolutive and reproducible electrophoregrams which could be considered as fingerprints of these strains. We first compared the presence or absence of bands and, afterwards, their intensity. The colour of the same bands from 2 identical preparations may vary even if the bacteria are grown under standard conditions. This did not affect the reproducibility of the methods, since the relative intensity of the bands within a strain remained constant. In addition, these methods were shown to discriminate the species $S$ thermophilus from other bacteria such as $L$ lactis, enterococci or $E$ coli screened in our laboratory (results not shown). The absence of molecular mass standards and/or different experimental conditions makes it difficult to compare our SDS-PAGE patterns with those already published (Jarvis and Wolff, 1979; Kalantzopoulos et al, 1990; Tsakalidou et al, 1992; Zourari et al, 1992) but proteins such as the 90-100 kDa protein (maybe pl 8.8 proteins) or major proteins in the range 40-66 kDa seemed to be characteristic of $S$ thermophilus strains.

As visualized in figures 1 and 2, proteins of different $S$ thermophilus strains display similar or almost identical patterns, and numerical analysis of densitometer scans of the gels yielded valuable information about the relation of the strains. For example, the strains CNRZ 455 and CNRZ 308 had similar correlation coefficients with the type strain ATCC 19258 ( $r=0.976$ and 0.992 , respectively) and consequently, could be clustered with each other. These 
results were in good agreement with the origin of these strains as CNRZ 308 or CNRZ 455, which have been isolated from a traditional Comté cheese starter. The protein profile of strain IP 6631 was different from other strains in SDS-PAGE but was similar in isoelectric focusing. Physiologically, it is a slow acidifying strain. It should be noted that this strain is found to be alone in a group of genetic homology (Colmin et al, 1991).

Our report included a comparative study of CNRZ 308 and PB18 growing in different conditions. Electrophoretic patterns show specific results about some proteins evolving with growing age of the cells or with medium, and this is significant in comparison to the reproducibility of the gels. The strain PB18, a high acidifying strain harboring a $3.5 \mathrm{kB}$ plasmid, was characterized by a major band which was visualized in the 2 electrophoretic patterns (18 kDa and pl 5.7). This probably corresponds to the same protein or group of proteins. This protein was more significantly expressed when PB18 was grown in non-buffered medium as TPPY or when the $\mathrm{pH}$ is low $(\mathrm{pH}=4.7)$ in a buffered medium.

In conclusion, the protein patterns of the strains studied present a high similarity, confirmed with 5 others strains (our laboratory, data not shown). Interestingly, it therefore follows that the bands distinguished in the patterns can be accepted as representing authentic indications of cell activity and it is attractive to speculate for a later isolation and functional study. This work is currently being expanded to include fresh M17 medium and more strains.

\section{REFERENCES}

Baer A (1987) Différenciation électrophorétique et immunologie de quelques lactobacilles. Schweiz Milchwirtsch Forsch 16, 84-88
Bracquart $P$ (1981) An agar medium for the differential enumeration of Streptococcus thermophilus and Lactobacillus bulgaricus in yoghurt. J Appl Bacteriol 51, 303-305

Bradford MM (1976) A rapid and sensitive method for the quantification of microgram quantities of protein utilizing the principle of protein dye-binding. Anal Biochem 72, 248-254

Colmin C, Pebay M, Simonet JM, Decaris B (1991) A species-specific DNA probe obtained from Streptococcus salivarius subsp thermophilus detects strain restriction polymorphism. FEMS Microbiol Lett 81, 123-128

Dicks LMT, van Vuuren HJJ (1987) Relatedness of heterofermentative Lactobacillus species revealed by numerical analysis of total soluble cell protein patterns. Int J Syst Bacteriol $37,437-440$

Elliott JA, Collins MD, Pigott NE, Facklam RR (1991) Differentiation of Lactococcus lactis and Lactococcus garviae from humans by comparison of whole-cell protein pattern. $J$ Clin Microbiol 29, 2731-2734

Hemme D, Nardi M (1980) Electrophorégrammes des protéines, de la bêtagalactosidase et de l'aldolase de Streptococcus thermophilus et des lactobacilles thermophiles. Leurs variations selon les souches et les conditions de culture. Lait 60, 375-392

Jackman PJH (1985) Bacterial taxonomy based on electrophoretic whole-cell protein patterns. In: Chemical Methods in Bacterial Systematics (M Goodfellow, DE Minnikin, eds) Academic Press, London, 115-129

Janis AW, Wolff JM (1979) Grouping of lactic streptococci by gel electrophoresis of soluble extracts. Appl Environ Microbiol 37, 391-398

Kalantzopoulos G, Tsakalidou E, Manolopoulou E (1990) Proteinase, peptidase and esterase activities of cell-free extracts from wild strains of Lactobacillus delbrueckii subsp bulgaricus and Streptococcus salivarius subsp thermophilus isolated from traditional Greek yogurts. J Dairy Res 57, 593-601

Kersters K, De Ley J (1975) Identification and grouping of bacteria by numerical analysis of their electrophoretic protein patterns. J Gen Microbiol 87, 333-342

Kersters K, Pot B (1991) Classification and identification methods for lactic acid bacteria, with emphasis on protein gel electrophoresis. Symposium Lactic 91, Caen, France 
Laemmli UK, Favre M (1973) Maturation of the head of bacteriophage T4. I. DNA packaging events. J Mol Biol 80, 575-599

Sanogo T, Paquet D, Aubert F, Linden G (1990) Proteolysis of $\alpha_{s 1}$-casein by papain in a complex environment. Influence of ionic strength on the reaction products. J Food Sci 55, 796800

Schleifer H, Kilpper-Bälz R (1987) Molecular and chemotaxonomic approaches to the classification of streptococci, enterococci and lactococci: a review. Syst Appl Microbiol 10, 1-19

Steck G, Leuthard P, Bürk RR (1980) Detection of basic proteins and low molecular weight peptides in polyacrylamide gels by formaldehyde fixation. Anal Biochem 107, 21-24
Terzaghi BE, Sandine WE (1975) Improved medium for lactic streptococci and their bacteriophages. Appl Microbiol 29, 807-813

Tsakalidou E, Zoidou E, Kalantzopoulos G (1992) SDS-polyacrylamide gel electrophoresis of cell proteins from Lactobacillus delbrueckii subsp bulgaricus and Streptococcus salivarius subsp thermophilus strains isolated from yoghurt and cheese. Milchwissenschaft 47, 296-297

Zourari A, Commissaire J, Desmazeaud MJ (1992) SDS-solubilized whole-cell protein patterns of Streptococcus salivarius subsp thermophilus and Lactobacillus delbrueckii subsp bulgaricus isolated from Greek yogurts. J Dairy Res 59, 105-109 